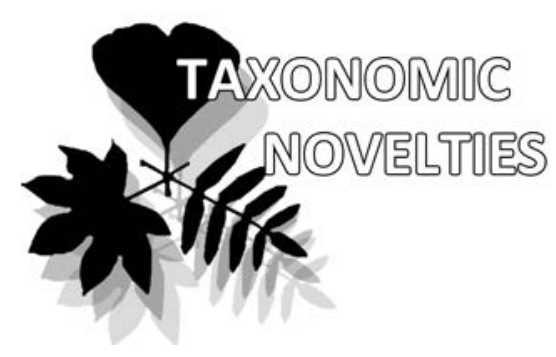

\title{
Unusual monstrose form of Neolentinus cyathiformis (Gloeophyllaceae, Basidiomycota) from the Novosibirsk Region (Russia)
}

\author{
Vyacheslav A. Vlasenko ${ }^{1 *}$, Ivan V. Zmitrovich ${ }^{2}$ \&
} Anastasia V. Vlasenko ${ }^{1}$

\section{Vyacheslav A. Vlasenko ${ }^{1 *}$ \\ e-mail: vlasenkomyces@mail.ru \\ Ivan V. Zmitrovich ${ }^{2}$ \\ e-mail: iv_zmitrovich@mail.ru \\ Anastasia V. Vlasenko ${ }^{1}$ \\ e-mail: anastasiamix81@mail.ru}

${ }^{1}$ Central Siberian Botanical Garden SB RAS, Novosibirsk, Russia

${ }^{2}$ V.L. Komarov Botanical Institute RAS, St. Petersburg, Russia

* corresponding author

Manuscript received: 07.08.2018

Review completed: 15.01.2019

Accepted for publication: 17.01.2019

Published online: 21.01.2019

\begin{abstract}
A B S T R A C T
A deviant form of wood-decaying basidiomycete Neolentinus cyathiformis found in the Novosibirsk Region is described as new to science. In this report, we provide the description and illustration of new taxon. Previously, monstrose forms have never been observed for this species. Morphological abnormalities leading to a total change in the habitus of the fruit body are more characteristic of another representative of the genus Neolentinus, $N$. lepideus. The described form is characterized by the presence of producing spores hymenial surface on the upper side of the cap of the fruit body on the outgrowths, in which the pits resembling the volcano's vents are located.
\end{abstract}

K e y w o r d s : Lentinoid fungi, morphological variability, monstrose forms, Neolentinus

\section{P E 3 Ю M E}

ВАасенко В.А., Змитрович И.В., ВАасенко А.В. Необычная монстрозная форма Neolentinus cyathiformis (Gloeophyllaceae) из Новосибирской области. Описана новая Аля науки монстрозная форма Аереворазрушающего базидиомицета Neolentinus cyathiformis, обнаруженная в Новосибирской области. Приводится описание и имлюстрация таксона. Ранее Аля Аанного вида монстрозные формы не отмечались. Описанная форма характеризуется наличием спороносящей гимениальной поверхности на верхней стороне шляпки плодового тела на выростах, в которых расположены ямки, напоминающие кратеры вулкана.

КАючевые слова: ^ентиноидные грибы, морфологическая изменчивость, монстрозная форма, Neolentinus
The genus Neolentinus includes nine species, including N. adhaerens (Alb. et Schwein.) Redhead et Ginns, N. cirrhosus (Fr.) Redhead et Ginns, N. dactyloides (Cleland) Redhead et Ginns, N. kauffmanii (A.H. Sm.) Redhead et Ginns, N. pallidus (Berk. et M.A. Curtis) Redhead et Ginns, N. papuanus (Hongo) Redhead et Ginns, N. ponderosus (O.K. Mill.) Redhead et Ginns, as well as N. cyathiformis (Schaeff.) Della Magg. et Trassin. and N. lepideus (Fr.) Redhead et Ginns, which are found in Russia.

In 1985, a new genus Neolentinus (type Lentinus kauffmanii A.H. Sm.) was segregated from the Lentinus (Redhead et al. 1985) on the basis of a specific rot character (brown rot). According to molecular phylogenies, the genus Neolentinus belongs to the order Gloeophyllales, unlike other species of the genus Lentinus connected to Polyporales (Hibbet et al. 2007). Later, Lentinus cyathiformis (Schaeff.) Bres. was transferred to the genus Neolentinus as N. cyathiformis (Schaeff.) Della Magg. et Trassin. (Della Maggiora 2014).

In nature, this fungus colonizes a dead wood of deciduous trees, where it produces a brown rot (Fig. 1: A-B). The $N$. cyathiformis grows on fallen trunks and stumps of Populus tremula in the south of Western Siberia (Vlasenko 2013). We noted that aspen in this region is a widespread substrate for wood decaying fungi (Vlasenko 2009). The only finding of this species is known on Tilia cordata in the Kemerovo Region (specimens are kept in NSK).

Morphological transformations leading to a total change in the habitus of the fruiting body are more characteristic of another species of this genus, $N$. lepideus, a monstrose form of which was described from Novosibirsk Region (Vlasenko et al. 2017).

Monstrose form of $N$. lepideus f. ceratoides does not produce spores and develops under dark conditions. It occurs on timber constructions in the caves, grottos, mines, cellars, basements and under the floor. Monstrose fruiting bodies have a horn form, outwardly resembling clavarioid fungi, and bear several elongated, round coralloid branches extending from a common trunk, which under normal conditions would have given a stipe. At the same time, the caps with lamellar hymenophore, which would appear on normal fruiting bodies, are completely absent.

Previously, a monstrose forms were not observed in $N$. cyathiformis. The presence of monstrose forms in several species of the genus Neolentinus may indicate that for a given taxon a deviating morphological forms might be quite usual. They normally appear in habitats with ecological parameters lying out of optimal ecological range of this species. 

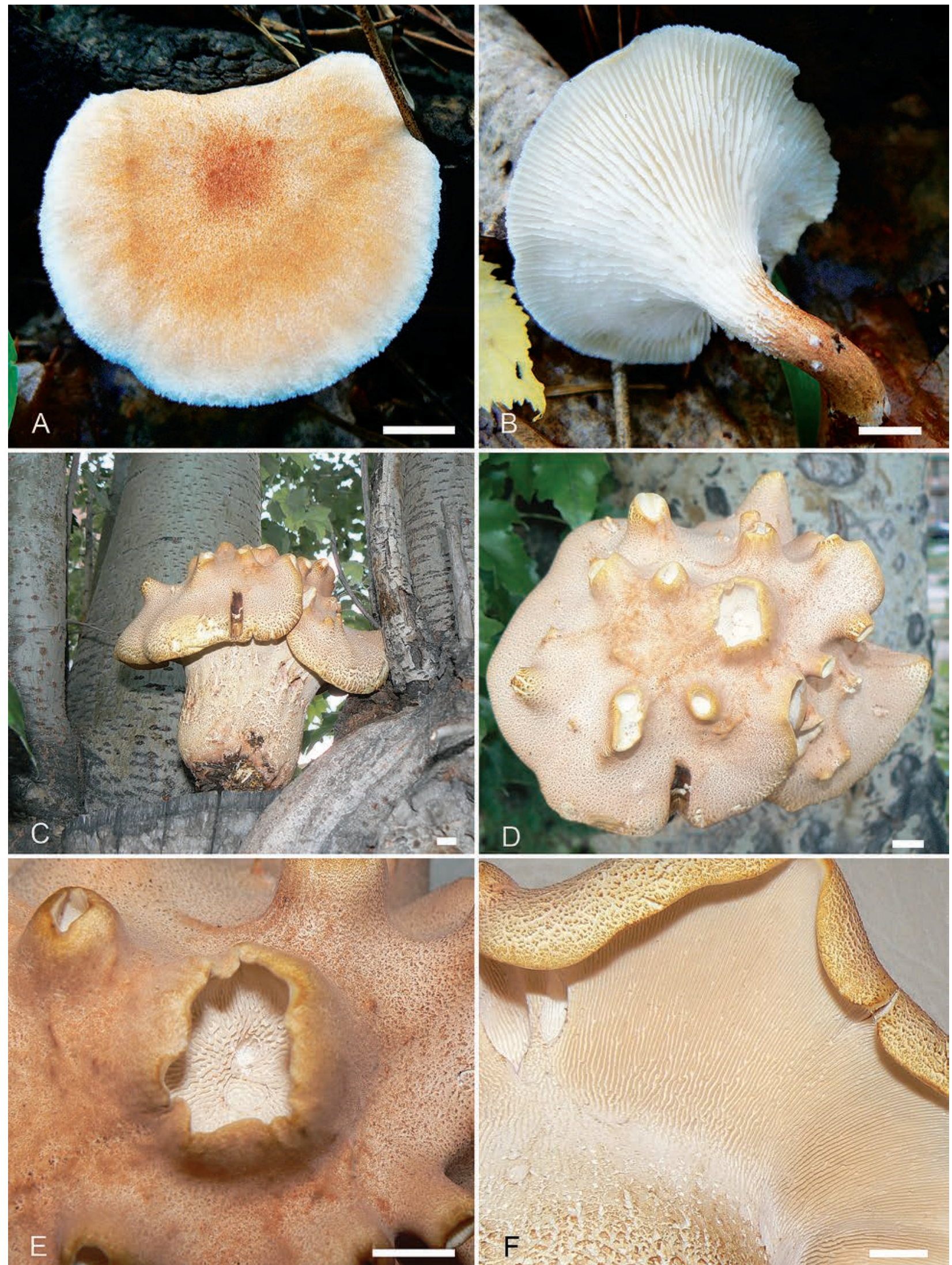

Figure 1 Fruiting bodies of typical and monstrose forms of Neolentinus cyathiformis. A, B - young fruiting body of Neolentinus cyathiformis, a typical lentinoid form in nature. Neolentinus cyathiformis (Schaeff.) Della Magg. et Trassin f. crateriformis V. Vlasenko, Zmitr. et A. Vlasenko forma nova: $\mathrm{C}$ - habitus of fruit body on the substrate in urban plantings; D - cap of fruit body, view from the upperside; $\mathrm{E}$ - hymenial surface on the upperside of the cap of the fruit body on the outgrowths in which the pits resembling the volcano's vents are located; F - typical hymenial surface from the bottom of the fruit body cap. Photos by: V. Vlasenko \& A. Vlasenko. Bars: $-1 \mathrm{~cm}$ 


\section{MATERIAL AND METHODS}

We studied morphology and anatomy of Neolentinus representatives kept in "Herbarium of vascular plants, lichens and fungi" (NSK), Novosibirsk with an aid of a light microscope Carl Zeiss Axioskop-40 and stereo microscope Carl Zeiss Stereo Discovery V 12. Stereomicroscope Carl Zeiss Stemi DV4 and light microscope Carl Zeiss Axiolab $\mathrm{RE}$ were used to the species identification.

For photographing fruiting bodies and habitats of fungi we used a Panasonic-Lumix DFC-XZ7 camera. For coloration microstructures in dried herbarium material the Cotton Blue reagent was used. The measurements of the spores were made for each studied specimens. Parameters of the basidiospores: $\mathrm{L}=$ mean spore length (arithmetical mean of all spores), $\mathrm{W}=$ mean spore width (arithmetical mean of all spores), $\mathrm{Q}=$ quotient of the mean spore length and the mean spore width $(\mathrm{L} / \mathrm{W}$ ratio), $\mathrm{Lm}, \mathrm{Wm}, \mathrm{Qm}=$ their average arithmetic meanings.

\section{TAXONOMIC TREATMENT}

Neolentinus cyathiformis (Schaeff.) Della Magg. et Trassin, 2014, Index Fungorum 171:1; 三 Agaricus cyathiformis Schaeff., 1774, Fung. bavar. palat. nasc. (Ratisbonae) 4:66; = Lentinus cyathiformis (Schaeff.) Bres., 1929, Iconogr. Mycol. 11 (Tab. 501-550): tab. 511; = Neolentinus schaefferi Redhead et Ginns, 1985, Trans. Mycol. Soc. Japan 26(3):357.

Description: Basidiomes annual, of lentinoid habitus, solitary or clustered, cyathiform with more or less central stem. Pileus convex, later flattening, finally concave. Upperside matt, cream to pale-colored with brick-brownish small scales or dots, brighter to the edge, mature fruit bodies uniformly colored. Margin enrolled when young, with a wrinkled lobate edge at maturity. Context white, unchanging in color, tough-fleshy when young, coriaceous when dry, having delicate taste and weak fruity odor. Lamellae of 2-3 levels, narrow in young, white, cream to pale-colored, thick in mature, decurrent on the stipe, serrate at maturity. Stipe central or somewhat eccentric, often curved, covered with converging lamellae, brick-brownish, later cream to pale-colored. Hyphal system dimitic. Generative hyphae 2.5-4 $\mu \mathrm{m}$ in diam., thin-walled, hyaline, with clamps. Skeletal hyphae 2.5-5 $\mu \mathrm{m}$ in diam., thick-walled, hyaline. Basidia 35-40 $\times$ 5-6 $\mu \mathrm{m}$, club-shaped. Numerous basidioles and pleurocystida present. Basidiospores 10-14 × 4-5 $\mu \mathrm{m}$, cylindric, hyaline, thin-walled, inamyloid, acyanophilous. Spore print white.

Habitat: on dead wood of Populus tremula, rarely Tilia cordata. Causes a brown rot.

Neolentinus cyathiformis f. crateriformis V. Vlasenko, Zmitr. et A. Vlasenko forma nova Fig. 1: C-F. MycoBank no: MB 827348

Description: Basidiomes annual, solitary, not becoming cyathiform, differentiated into stipe and hemispheric pileus. Pileus constantly convex, up to $14 \mathrm{~cm}$ in diameter, up to $4 \mathrm{~cm}$ in width, cream to pale-colored with evenly scattered brickbrownish small scales, with a more intense brownish tinge in places of accumulation of scales, furnished by multiple crateriform rounded depressions bearing radially oriented sporulating lamellae upper surface. Context white, unchanging in color, tough-fleshy when young, coriaceous when dry, having delicate taste and weak fruity odor. Lamellae of
2-3 levels, narrow in young, white, cream to pale-colored, thick in mature, decurrent on the stipe, serrate at maturity. Stipe central or somewhat eccentric, often curved, covered with converging lamellae, brick-brownish, later cream to pale-colored. Hyphal system dimitic. Generative hyphae 2.5-3.5 $\mu \mathrm{m}$ in diam., thin-walled, hyaline, with clamps. Skeletal hyphae $2.5-5 \mu \mathrm{m}$ in diam., thick-walled, hyaline. Basidia 35-40 × 3.5-5 $\mu \mathrm{m}$, club-shaped. Spores 6.9-8.70 $\times 2.7-4.2 \mu \mathrm{m}, \operatorname{Lm} 7.87 \mu \mathrm{m}, \mathrm{Wm} 3.62 \mu \mathrm{m}, \mathrm{Q} 2.55-2.07 \mu \mathrm{m}$, Qm $1.23 \mu \mathrm{m}$, ellipsoid, hyaline, thin-walled, inamyloid, acyanophilous. Spore print white.

Etymology: furnished by multiplecrateres.

Typus (designated here): RUSSIA. Novosibirsk Region, Novosibirsk city, Sovetskiy district, st. Ivanova 11, urban plantings, on the living tree of Populus alba L., in a crevice in place saw cut main trunk $54^{\circ} 52^{\prime} 0.08^{\prime \prime} \mathrm{N} 83^{\circ} 5^{\prime} 11.85^{\prime \prime} \mathrm{E}$ $129 \mathrm{~m}$ alt. Coll. A.V. Vlasenko \& V.A. Vlasenko 12 July 2012 (holotype NSK 1013003).

Habitat: in the hollows of the trunks of weakened living trees Populus alba.

Distribution: currently known only from Western Siberia, Novosibirsk Region.

Comments. This new form of N. cyathiformis does not resemble a typical lentinoid morphotype and is clearly distinguished by several morphological features. The stipe of $N$. cyathiformis $\mathrm{f}$. crateriformis is short, but very thick $(7 \mathrm{~cm}$ thick), in the form of hemp. The pileus, unlike the typical form, with a poorly developed hymenophore on the underside. But the surface of the cap is furnished by outgrowths, in which the pits resembling the volcano's vents are located. Micromorphologically, the specimen is characterized by spores of a smaller sizes.

We described a new form of $N$. cyathiformis $\mathrm{f}$. crateriformis as new for science, with the aim of taxonomic fixation of the appearance of wide range polymorphism of the lentinoid fungi. Unlike to the closely related taxon $N$. lepideus f. ceratoides, whose deviant morphogenesis is caused by the absence of light, the effect of environmental conditions, with uncharacteristic parameters of environmental factors such as temperature, humidity, and illumination, seemingly not traced in the form of the fungus described by us. The reasons for the appearance of this form, possibly, are due to the position of the fruit body of the fungus on the substrate, which developed in the crevice of the trunk.

It is possible, however, an explanation of such phenomenon through the concept of insolation niche (Zmitrovich 2017). Within frameworks of this concept, the positive geotropism of hymenophore, which turns out to be more sensitive in air humidity (Gorovoy 1990), can be interpreted on the basis of topological features of mycelial formation: in resupinate forms, developing from underside of horizontally oriented substrate, the fountain growth of hyphal mass is determined by positive phototropism and is limited by a decrease in relative humidity of air as it approaches the boundary of substrate substrate-shaded zone; in hymenophore, developing on caps and consolelike basidiomata, the hymenophore development also goes towards the border of shadow zone. The conditions of shaded hollow where the described fungus was developed 
could imitate the conditions of shadow zone of underside of the cap, so the hymenophore began to form not only on internal, but also on externa side of the cap.

\section{ACKNOWLEDGEMENTS}

The work of V.A. Vlasenko and A.V. Vlasenko was carried out in frame of the State Task AAAA-A17-117012610055-3 of Central Siberian Botanical Garden of Siberian Branch of the Russian Academy of Sciences. The article uses the herbarium specimens of Bioresources scientific collection of CSBG SB RAS (USU 440537) Herbarium of higher vascular plants, lichens and fungi (NSK). The work of I.V. Zmitrovich was carried out in frame of the State Task AAAA-A18-118031290108-6 of Komarov Botanical Institute of the Russian Academy of Sciences.

\section{LITERATURE CITED}

Bondartseva, M.A., I.V. Zmitrovich \& G.I. Zarudnaya 2016. New combination for the sterile form of Neolentinus lepideus (Gloeophyllales, Agaricomycetes). Mikologiya i Fitopatologiya 50(3):195-197.

Della Maggiora, M. 2014. Nomenclatural novelties. Index Fungorum 171:1.

Gorovoy, L.F. 1990. Morphogenesis of gilled fungi. Naukova

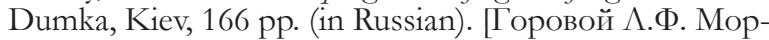
фогенез пластинчатых грибов. Киев: Наукова Аумка. 1990. 166 c.].
Hibbett, D.S., M. Binder, J.F. Bischoff, M. Blackwell, P.F. Cannon, O.E. Eriksson, S. Huhndorf, et al. 2007. A higher-level phylogenetic classification of the Fungi. Mycological Research 111(5):509-547.

Redhead, S.A. \& J.H. Ginns 1985. A reappraisal of agaric genera associated with brown rots of wood. Transactions of the Mycological Society of Japan 26(3):349-382.

Vlasenko, V.A. 2009. Substrate specialization of wood-decay Aphyllophoroid fungi in the pine forest of the right riverside of the Ob Headwaters. Contemporary Problems of Ecology 2(6):620-624.

Vlasenko, V.A. 2013. Aphyllophoroid fungi of pine forests on the right bank of the upper Ob region. GEO, Novosibirsk, 105 pp. ВАасенко В.А. 2013. Афимлофороилные грибы сосновых месов правобережья Верхнего Приобья. Новосибирск: ГЕО. 105 с.]

Vlasenko, V.A., A.V. Vlasenko \& I.V. Zmitrovich 2017. First record of Neolentinus lepideus f. ceratoides (Gloeophyllales, Basidiomycota) in Novosibirsk Region. Current Research in Environmental \& Applied Mycology 7(3):187-192.

Zmitrovich, I.V. 2017. Phylogenesis and adaptatiogenesis of polyporaceous fungi (family Polyporaceae s. str.). Dr. Sci. Thesis. Saint Petersburg, 364 pp. (in Russian). [Змитрович И.В. 2017. Филогенез и адаптациогенез полипоровых грибов (семейство Polyporaceae s. str.). Аиссертация на соискание ученой степени Аоктора биологических наук. Санкт-Петербург. 364 с.]. 